\title{
Analisis Fatigue Life Pada Konversi LCT Menggunakan Metode Spectral Fatigue
}

\author{
Raja Andhika Rizki Ramadhani, M. Nurul Misbah, Septia Hardy Sujiatanti \\ Departemen Teknik Perkapalan, Fakultas Teknologi Kelautan, Institut Teknologi Sepuluh Nopember (ITS) \\ e-mail:mnmisbah@na.its.ac.id, septi@na.its.ac.id
}

\begin{abstract}
Abstrak-Kapal yang beroperasi di Indonesia tentunya sangat beragam, salah satunya yaitu landing craft tank atau LCT. Kapal tersebut LCT banyak yang telah dikonversi menjadi kapal penumpang yang beroperasi pada Selat Bali. Kapal tersebut beroperasi dan mengalami beban berulang. Beban berulang tersebut merupakan momen lengkung vertikal dan horizontal yang beroperasi acak terhadap gelombang yang terjadi. Beban lengkung tersebut akan mengakibatkan suatu bagian konstruksi mendapatkan beban lelah atau fatigue. Karena beban berulang tersebut terus terjadi dan akan membahayakan keselamatan kapal, maka diperlukan perhitungan fatigue. Tujuan dari penelitian ini ialah memprediksi umur struktur kapal. Terdapat banyak metode perhitungan fatigue yang salah satunya yaitu dengan metode spectral fatigue. Analisis kapasitas lelah dengan spectral fatigue menggunakan variasi sudut hadap, kasus pembebanan, dan spektrum gelombang pada tiap sea state. Penggunaan software elemen hingga untuk membantu mendapatkan tujuan dengan skenario variasi yang telah disebutkan. Software yang digunakan yaitu software yang menganalisis respon gerak dan beban kapal terhadap variasi dengan bentuk elemen surface. Dari software tersebut akan didapatkan tegangan yang terjadi yang nantinya akan digunakan pendekatan statistik dalam ruang frekuensi untuk menghitung kapasitas lelah. Hasil analisis menunjukkan tegangan terbesar terjadi pada sudut hadap $135^{\circ}$ atau quartering sea. Akibat tegangan tersebut didapatkan umur lelah dari masing-masing kasus pembebanan yaitu 20,13 tahun dan 31,30 tahun secara beruturut-turut untuk muatan penuh dan muatan kosong. Sehingga, umur lelah kombinasi tegangan yaitu 28,83 tahun. Dari penelitian yang dilakukan, dapat disimpulkan bahwa umur struktur dari kapal tersebut yaitu 28 tahun dan memenuhi kriteria yang ada dengan margin 8 tahun dari tahun desainnya yatu 20 tahun.
\end{abstract}

Kata Kunci-Spectral Fatigue, Momen Lengkung, Spektrum Gelombang, LCT.

\section{PENDAHULUAN}

$\mathrm{K}$ APAL yang berada pada suatu perairan mengalami olah gerak secara acak yang diakibatkan oleh tinggi dan periode gelombang. Olah gerak tersebut mengakibatkan beban siklik. Beban siklik tersebut akan mengakibatkan suatu struktur kapal mengalami lelah. Kelelahan tersebut perlu dianalisis untuk menjamin keselamatan kapal. Salah satu metode untuk menganalisis hal tersebut yaitu spectral fatigue dan dibantu dengan elemen hingga. Analisis kelelahan tersebut dikembangkan untuk menghitung perkiraan umur suatu struktur kapal sebagai parameter kemanan kapal beroperasi.
Penelitian dilakukan untuk menghitung hal teknis yang diperlukan untuk analisis fatigue. Hal teknis tersebut yaitu spektrum gelombang, respons struktur terhadap gelombang, tegangan pada titik tinjau dan umur struktur yang ditinjau. Penelitian ini menggunakan metode spectral fatigue. Metode spectral fatigue yaitu metode dimana di dalamnya menggunakan pendekatan statistika.

\section{TINJAUAN PUSTAKA}

\section{A. Gelombang Laut}

Laut memiliki kondisi yang berbeda-beda di setiap tempat tergantung dari kondisi alam yang mempengaruhinya. Gelombang laut dipengaruhi oleh dalam atau tidaknya suatu perairan. Oleh karena itu bentuk dan sifat gelombang sangatlah kompleks. Gelombang dibedakan menjadi dua macam, yaitu gelombang sinusoidal dan gelombang trochoidal. Karena jenis gelombang tersebut sangat kompleks maka untuk melakukan perhitungan ilmiah dilakukan pendekatan agar dapat digambarkan sifat dari gelombang yang kita gunakan [1]. Pernyataan tersebut dapat diformulasikan pada persamaan (1).

$$
T_{z}=2 \pi \sqrt{\frac{m_{0}}{m_{2}}}
$$

Dimana nilai $\mathrm{T}_{\mathrm{z}}=$ periode zero up crossing ( $\mathrm{s}$ ) $\mathrm{m}_{0}=$ spektral momen orde ke- 0 dan $\mathrm{m}_{2}=$ spektral momen orde ke2.

\section{B. Wave Scatter Diagram}

Wave scatter diagram adalah tabel hubungan dimana menunjukkan hubungan antara tinggi signifikan gelombang (Hs) dan periode zero-up crossing $\left(\mathrm{T}_{\mathrm{z}}\right)$ yang dinotasikan dengan banyaknya kejadian gelombang tersebut. Tiap 1 tabel dapat diartikan sebagai 1 short-term wave analysis [2].

\section{Spektrum Gelombang}

Data gelombang yang diukur direpresentasikan dalam bentuk spektrum gelombang untuk analisis selanjutnya. Spektrum gelombang tersebut direpresentasikan untuk tiap sea-state. Spektrum gelombang yang dipakai memiliki 2 parameter yaitu tinggi gelombang signifikan (Hs) dan periode zero-up crossing (Tz). Spektrum tersebut dapat direpresentasikan dalam spektrum Pierson-Moskowitz [2]. Spektrum tersebut dapat diformulasikan pada persamaan (2). 


$$
S_{(P M)}=\frac{H s}{4 \pi}\left(\frac{2 \pi}{T_{z}}\right) \omega^{-5} \exp \left[-\frac{1}{\pi}\left(\frac{2 \pi}{T_{z}}\right)^{4} \omega^{-4}\right]
$$

Dimana $\mathrm{S}_{(\mathrm{PM})}=$ spektrum gelombang Pierson-Moskowitz, nilai $\mathrm{Hs}=$ tinggi signifikan gelombang $(\mathrm{m}), \mathrm{Tz}=$ periode zero up crossing (s), dan $\omega=$ frekuensi gelombang $(\mathrm{rad} / \mathrm{s})$.

Hasselmann et al menemukan bahwa terdapat faktor tambahan pada spektrum yang sebelumnya sudah dikembangkan yaitu Pierson-Moskowitz. Maka, JONSWAP spektrum adalah spektrum Pierson-Moskowitz yang dikalikan dengan faktor peak enhancement $\gamma^{\mathrm{r}}$ [3]. Sehingga spektrum gelombang dapat diubah menjadi persamaan (3).

$$
S_{(J W P)}=S_{(P M)} \gamma^{r}
$$

Dimana, nilai $\mathrm{S}_{(\mathrm{JWP})}=$ spektrum gelombang JONSWAP, $\gamma$ $=$ peak enhancement yang besarnya 2,5, dan $\mathrm{r}=$ faktor peak enhancement.

\section{Tegangan}

Tegangan yang terjadi pada kapal dapat terjadi dari berbagai sumber beban. Tegangan yang diakibatkan beban gelombang dapat dilakukan sesuai dengan momen lengkung yang terjadi pada kapal yaitu horizontal dan vertikal. Formulasi tegangan dapat diformulasikan yaitu dari persamaan (4) hingga persamaan (6).

$$
\begin{aligned}
\sigma_{H} & =\frac{M_{z}}{I_{C L}} y \\
\sigma_{V} & =\frac{M_{y}}{I_{N A}} z \\
\sigma_{T} & =\sqrt{{\sigma_{H}}^{2}+\sigma_{V}{ }^{2}}
\end{aligned}
$$

Dimana nilai $\sigma=$ tegangan $\left(\mathrm{N} / \mathrm{m}^{2}\right), \mathrm{M}=$ momen lengkung $(\mathrm{Nm}), \mathrm{I}=$ momen inersia penampang $\left(\mathrm{m}^{3}\right)$, dan $\mathrm{z}, \mathrm{y}=$ jarak titik tinjau dari titik neutral axis atau centerline (m).

Analisis tegangan sebelumnya banyak dilakukan pada bidang perkapalan. Salah satunya yaitu pengecekan kekuatan. Pengecekan kekuatan yang dilakukan dibagi menjadi dua yaitu global dan local. Untuk analisis global dapat diperhatikan pada penelitian yang dilakukan Misbah et al, 2018, melakukan analisis kekuatan memanjang dari kapal yang sama dan diverifikasi dengan rule yang tertera pada BKI. Perhitungan analisis dilakukan dengan 4 kasus pembebanan yaitu (1) muatan kosong pada kondisi sagging, (2) muatan kosong pada kondisi hogging, (3) muatan penuh pada kondisi sagging dan (4) muatan penuh pada kondisi hogging. Perhitungan dilakukan dengan software FEA untuk nilai tegangan. Hasil menunjukkan bahwa tegangan pada masing-masing kondisi yaitu (1) $72,393 \mathrm{MPa}$, (2) 74,792 MPa, (3) 129,92 MPa dan (4) 132,4 MPa [4].

Sedangkan untuk analisis local dapat diperhatikan penelitian kekuatan. Pada penelitian yang dilakukan oleh Ardianus et al, 2017, melakukan analisis tegangan sekat melintang antara corrugated bulkhead dan transverse bulkhead. Hasil dari penelitian yaitu tegangan dan berat yang lebih efektif yaitu pada penggunaan corrugated bulkhead. Hasil teknis didapatkan bahwa tegangan terkecil dan deformasi terkecil terjadi pada corrugated bulkhead sebesar $76,6 \mathrm{~N} / \mathrm{mm}^{2}$ dengan sudut $45^{\circ}$ dan $2,48 \mathrm{~mm}$ secara berturutturut [5].

\section{E. Response Amplitude Operator}

Response Amplitude Operator (RAO) juga disebut sebagai karakter suatu struktur pada gelombang regular. RAO adalah fungsi dari amplitudo gerakan struktur terhadap amplitude gelombang [6]. Formulasi RAO dapat diformulasikan pada persamaan (7).

$$
R A O_{M}=\frac{M}{Z_{a}}
$$

Dimana nilai $\mathrm{RAO}_{\mathrm{M}}=$ response amplitude operator $(\mathrm{Nm} / \mathrm{m}), \mathrm{M}=$ momen lengkung $(\mathrm{Nm})$, dan $\mathrm{Z}_{\mathrm{a}}=$ amplitudo gelombang.

\section{F. Response Spectrum}

Response struktur pada gelombang irregular dapat dilakukan dengan mentransformasikan spektrum gelombang menjadi spectrum response. Spektrum response didefiniskan sebagai respons kerapatan energi pada struktur akibat gelombang. Hal ini dapat dilakukan dengan mengalikan harga kuadrat dari RAO dengan spektrum gelombang encounter [1]. Formulasi tersebut dapat diperhatikan pada persamaan (8).

$$
S_{(R)}=R A O^{2} \times S_{\left(\omega_{e}\right)}
$$

Dimana nilai $\mathrm{S}_{(\mathrm{R})}=$ spektrum response, $\mathrm{RAO}=$ response amplitude operator dan $\mathbf{S}_{(\omega \mathrm{e})}=$ spektrum gelombang dalam ruang frekuensi encounter.

\section{G. Spectral Moment}

Untuk mengetahui secara statistik perilaku dari struktur pada gelombang, maka dapat diterjemahkan dari spektral moment. Spektral moment tersebut digunakan dalam analisis seakeeping dari struktur [2]. Formulasi Spectral Moment dapat dilihat pada persamaan (9).

$$
m_{(n)}=\int_{0}^{\infty} \omega_{e}^{n} S_{(R)} d \omega
$$

Dimana nilai $\mathrm{m}_{\mathrm{n}}=$ spektral momen orde ke- $\mathrm{n}, \mathrm{S}_{(\mathrm{R})}=$ spektrum response dan $\omega_{\mathrm{e}}=$ frekuensi gelombang encounter $(\mathrm{rad} / \mathrm{s})$.

\section{H. $S$-N Diagram}

S-N diagram didapatkan dari percobaan beberapa material yang diberi beban tegangan yang berfluktuasi sesuai dengan regular sinusoidal. Proses tersebut pada umumnya dinamakan coupon testing [7]. Formulasi S-N Diagram dapat diperhatikan pada persamaan (10). 


$$
S^{m} N=A
$$

Dimana nilai $\mathrm{S}=$ rentang tegangan $(\mathrm{MPa}), \mathrm{m}=$ inverse slope, $\mathrm{N}=$ daya tahan struktur, dan $\mathrm{A}=$ fatigue strength coefficient.

\section{Kelelahan \& Umur Struktur}

Analisis fatigue untuk metode spektral memodifikasi rumus dari Palgrem-Miner menjadi formulasi matematis. Formulasi matematis tersebut berlaku pada tiap sea-state [2]. Formulasi damage yaitu pada persamaan (11).

$$
D=\frac{T}{A}(2 \sqrt{2})^{m} \Gamma\left(\frac{m}{2}+1\right) \sum_{1}^{M} \lambda\left(m, \varepsilon_{i}\right) f_{0 i} p_{0 i}\left(\sigma_{i}\right)^{m}
$$

Dimana nilai $\mathrm{D}=$ kerusakan, $\mathrm{T}=$ design life $\mathrm{m}=$ inverse slope, $\Gamma=$ fungsi gamma, $\lambda\left(\mathrm{m}, \varepsilon_{\mathrm{i}}\right)=$ koreksi Monte Carlo, $\mathrm{f}_{0 \mathrm{i}}=$ frekuensi kejadian sea state, $\mathrm{p}_{0 \mathrm{i}}=$ probabilitas kejadian sea state dan $\sigma_{i}=$ standar deviasi proses tegangan.

Penelitian fatigue banyak dilakukan sebelumnya dan didominasi oleh dua metode yaitu simplified dan spectral. Metode simplified yaitu metode dimana model jumlah kejadian diasumsikan. Sedangkan spectral yaitu menggunakan data langsung kejadian gelombang dari titik yang ditinjau. Untuk penelitian simplified dapat diperhatikan pada penelitian sebagai berikut:

1.Penelitian yang dilakukan oleh Dita et al, 2012 melakukan perhitungan perkiraan umur untuk struktur kapal tanker. Acuan yang dipakai mengacu pada Common Structural Rules (CSR). Nantinya tanker tersebut akan dikonversi menjadi FPSO. Perkiraan umur struktur didapatkan selama 26 tahun dimana titik kritis terjadi pada web frame nomor 7 di midship [8].

2. Penelitian yang dilakukan oleh Rusdi et al, 2018, dilakukan pada struktur kapal tanker. Beban yang diacu yaitu beban sloshing saja. Skenario beban sebanyak 4 buah yaitu $0.3 \mathrm{~h}, 0.6 \mathrm{~h}, 0.7 \mathrm{~h}$ dan $0.95 \mathrm{~h}$. Dengan mengacu pada titik tinjau berupa bracket maka akan didapatkan hasil fatigue life pada titik tinjau selama 450 tahun $(0.3 \mathrm{~h}), 84$ tahun $(0.6 \mathrm{~h}), 76$ tahun (0.7h) dan 137 tahun (0.95h) [9].

3. Penelitian yang dilakukan oleh Huda \& Santosa, 2012, dilakukan pada kapal ikan 10 GT. Dengan jarak pisah (S/L) yaitu 0,3 dan berbahan ASTM A516-70. Hasil dari perkiraan umur yaitu selama 26,4 tahun. Standar yang digunakan yaitu selama 25 tahun [10].

Sedangkan penelitian yang menggunakan spectral fatigue juga banyak telah dilakukan. Salah satunya yaitu pada Keel Buoy Tsunami. dapat diperhatikan pada penelitian yang dilakukan oleh Yustiawan \& Suastika, 2012, dilakukan pada struktur Keel Buoy Tsunami yang mengalami beban berulang dari gelombang. Hasil dari penelitian ini didapatkan bahwa umur struktur tersebut selama 11 tahun [11].

Sehingga untuk menghitung fatigue life atau umur struktur dapat dilakukan dengan membagi design life dengan besar damage [2]. Formulasi umur yaitu pada persamaan (14).
$F L=\frac{T}{D}$

Dimana nilai $\mathrm{FL}=$ fatigue life, $\mathrm{T}=$ design life, dan $\mathrm{D}=$ kerusakan.

Perhitungan fatigue life dengan kombinasi kasus pembebanan dapat dilakukan dengan faktor $\alpha_{\mathrm{s}}$ atau faktor penggunaan kapal selama di laut sebesar 0,85 [2]. Formulasi tersebut dapat diperhatikan pada persamaan (15).

$L_{c}=\frac{1}{\alpha_{s}\left[\frac{1}{L_{1}}+\frac{1}{L_{2}}+\ldots+\frac{1}{L_{n}}\right]}$

Dimana nilai $\mathrm{L}_{\mathrm{c}}=$ fatigue life kombinasi dan $\mathrm{L}_{\mathrm{n}}=$ fatigue life per kasus pembebanan.

\section{J. Konversi LCT Menjadi Kapal Penumpang}

Penelitian yang dilakukan oleh Rohmadhana \& Kurniawati, 2016, dilakukan untuk meneliti konversi LCT. Dengan melihat peraturan pemerintah yang melarang beroperasinya kembali LCT sehingga harus diadakan konversi. Didapatkan bahwa setelah dikonversi kapal dapat mengangkut 96 penumpang, 12 truk, dan, 8 mobil. Tegangan konstruksi maksimal yaitu $1.248,957 \mathrm{~kg} / \mathrm{cm}^{2}$, sarat maksimum 2,193 m, tonase sebesar $551 \mathrm{GT}$ dan kondisi Intact Stability Code Reg. III/3.1I memenuhi. Biaya yang diperlukan untuk konversi yaitu Rp. 2.000.640.524 [13].

\section{METODOLOGI}

Metodologi pengerjaan dari penelitian ini dapat dipersingkat dengan diagram alir. Diagram alir tersebut dapat diperhatikan pada Gambar 1.

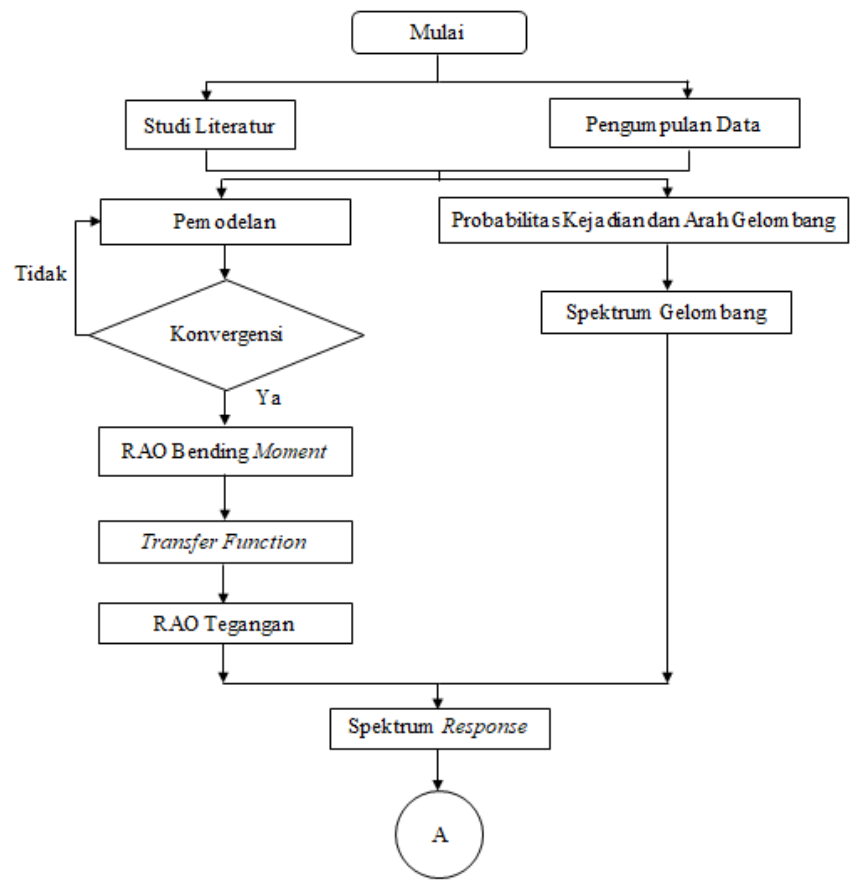




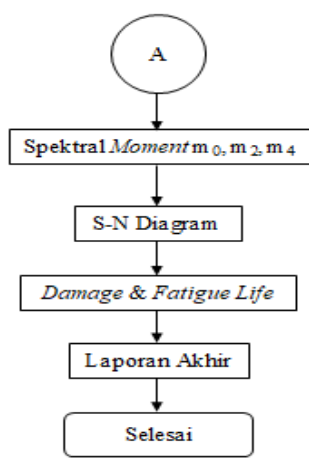

Gambar 1. Diagram alir penelitian.

Tabel 1. Modulus Penampang Kapal

\begin{tabular}{cll}
\hline \hline Parameter & Besar & Satuan \\
\hline $\mathrm{I}_{\mathrm{NA}}$ & 142196979,6 & $\mathrm{~cm}^{4}$ \\
$\mathrm{I}_{\mathrm{CL}}$ & 1460805765 & $\mathrm{~cm}^{4}$ \\
$\mathrm{Z}_{1}$ & 170,5 & $\mathrm{~cm}$ \\
$\mathrm{y}_{1}$ & 0 & $\mathrm{~cm}$ \\
\hline \hline
\end{tabular}

Seperti yang disinggung sebelumnya, diawali dengan teoriteori terkait digunakan pada proses pengerjaan penelitian dan pengumpulan data terlebih dahulu dikerjakan. Dari teori dan data yang sudah dikumpulkan selanjutnyadilakukan pemodelan lambung untuk menentukan RAO bending moment seperti persamaan (7) yang nantinya akan diubah menjadi fungsi transfer atau RAO tegangan seperti persamaan (4) hingga persamaan (6). Selain itu, seiring dengan memodelkan lambung tabel probabilitas dan spektrum gelombang juga dimodelkan menggunakan spektrum JONSWAP sesuai persamaan (3). Selanjutnya akan didapatkan spektrum response dari masing-masing sea state sesuai persamaan (8). Response tersebut yang selanjutnya diteliti secara statistika dengan menentukan besaran-besaran spectral moment baik orde ke-0, ke-2, dan ke-4 mengacu pada persamaan (9). Selanjutnya, perhitungan damage dilakukan dengan menggabungkan hubungan antara spectral moment, koreksi dan S-N diagram dimulai dari persamaan (9) hingga persamaan (12). Tahap terakhir dari penelitian ini ialah menentukan umur struktur penggabungan dari semua kasus pembebanan mengacu pada persamaan (12) dan persamaan (13).

\section{HASIL DAN PEMBAHASAN}

\section{A. Modulus Penampang}

Modulus penampang vertikal dan horizontal dapat dicari dengan cara menghitung per bagian dari konstruksi kapal terhadap baseline atau deck dan centerline. Output dari perhitungan ini yaitu $\mathrm{I}_{\mathrm{NA}}, \mathrm{z}_{1} \mathrm{I}_{\mathrm{CL}}$ dan $\mathrm{y}_{1}$. Hasil perhitungan dapat dilihat pada Tabel 1.

\section{B. Distribusi Berat}

Distribusi berat untuk kasus pembebanan muatan penuh dan muatan kosong diambil dari laporan stabilitas kapal. Hasil pemilihan tersebut dapat dilihat pada Tabel 2.
Tabel 2.

Distribusi Berat dan Gaya Angkat

\begin{tabular}{llrr}
\hline \multicolumn{4}{c}{ Distribusi Berat dan Gaya Angkat } \\
\multicolumn{4}{c}{ Load Case } \\
Data & Unit & Penuh & \multicolumn{1}{c}{ Ballast } \\
\hline Weight Distribution & & \\
LWT & ton & 712,1 & 712,1 \\
DWT & ton & 811 & 638 \\
Total & ton & 1523,1 & 1350,1 \\
Buoyancy \& Mass & Center Properties \\
T & $\mathrm{m}$ & \\
VCB & $\mathrm{m}$ & 2,351 & 2,118 \\
LCB & $\mathrm{m}$ & 1,25 & 1,13 \\
VCG & $\mathrm{m}$ & 25,71 & 25,93 \\
LCG & $\mathrm{m}$ & 4,19 & 3,15 \\
Displacement \& Vol. Displacement & 25,75 & 25,96 \\
$\Delta$ & ton & 1523,1 & \\
Vol. D & $\mathrm{m}^{3}$ & 1485,951 & 1350,1 \\
\hline \multicolumn{4}{c}{}
\end{tabular}

\section{S-N Diagram}

Pemilihan titik tinjau untuk S-N Diagram dipilih berdasarkan keselamatan kapal. Hasil pemilihan tersebut dapat dilihat pada Tabel 3. Titik tinjau yang diambil yaitu pada daerah Midship (Fr. 15) dan pada bracket terluar (starboard).

Tabel 3.

Parameter S-N Diagram

\begin{tabular}{cl}
\hline \hline Parameter & Besar \\
\hline $\mathrm{m}$ & 3 \\
$\mathrm{~A}$ & $4,31 \times 10^{11}$ \\
\hline \hline
\end{tabular}

\section{Pemodelan Lambung}

Pemodelan lambung dilakukan dengan software elemen hingga. Didapatkan bahwa nilai konstan beban yang diakibatkan karena keberadaan struktur pada gelombang terjadi pada ukuran elemen 1,7 m. Hasil tersebut dapat dilihat pada Gambar 2, Gambar 3, Tabel 4 dan Tabel 5.

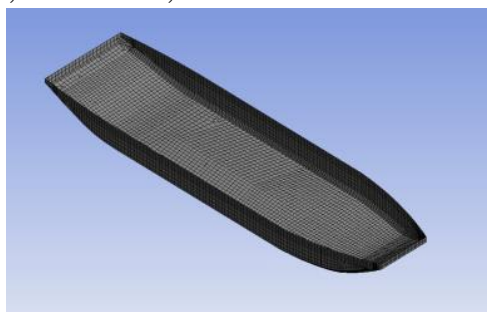

Gambar 2. Pembagian elemen hingga lambung.

Dapat diperhatikan pada Gambar 1 bahwa lambung kapal dibagi menjadi panel elemen. Pembagian panel digunakan untuk analisis elemen hingga.

Tabel 4.

\begin{tabular}{ccc}
\multicolumn{3}{c}{ Hasil Variasi Ukuran Elemen \& Bending Moment } \\
\hline Size $(\mathrm{m})$ & Element & Bending Moment $\mathrm{x} 10^{6}(\mathrm{Nm})$ \\
\hline 2 & 3482 & 78,986 \\
1,9 & 3640 & 78,987 \\
1,8 & 3676 & 78,986 \\
1,7 & 3766 & 78,986 \\
1,6 & 3807 & 78,986 \\
\hline \hline
\end{tabular}

Tabel 5.

Nilai Selisih Bending Moment Per Run

\begin{tabular}{ccc}
\hline \hline Run ke-N & Run ke-N+1 & Selisih \\
\hline 1 & 2 & $0,0016 \%$ \\
2 & 3 & $0,0012 \%$ \\
3 & 4 & $0,0001 \%$ \\
4 & 5 & $0,0000 \%$ \\
\hline \hline
\end{tabular}




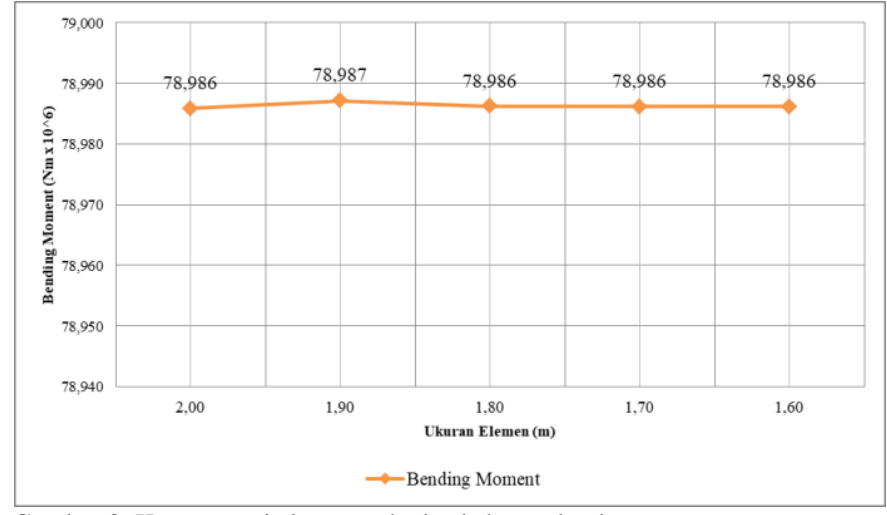

Gambar 3. Konvergensi elemen terhadap beban gelombang.

Dapat diperhatikan pada Tabel 4, Tabel 5, dan Gambar 3 bahwa hasil momen lengkung tidak signifikan terhadap ukuran elemen. Sehingga dapat diperhatikan pada run 3 dan run 4 tidak memiliki perbedaan yang signifikan sehingga diambil ukuran $1,7 \mathrm{~m}$.

\section{E. Data Gelombang}

Diagram wave scatter diagram terdiri dari tinggi gelombang signifikan (Hs) dan periode zero-up crossing (Tz). Pengolahan data tersebut dapat dilihat pada Tabel 6.

Tabel 6.

Data Gelombang Selat Bali [14]

\begin{tabular}{cccc}
\hline \hline \multirow{2}{*}{$\mathrm{Hs}(\mathrm{m})$} & \multicolumn{3}{c}{$\mathrm{Tz}(\mathrm{s})$} \\
\cline { 2 - 4 } & 5 & 6 & 7 \\
\hline 1 & 5887 & 58061 & 14947 \\
1.5 & 0 & 3856 & 8493 \\
2 & 0 & 2 & 460 \\
2.5 & 0 & 1 & 18 \\
\hline \hline
\end{tabular}

Pada Tabel 6 maka dapat disimpulkan bahwa pada Hs $=1$ $\mathrm{m}$ dan $\mathrm{Tz}=6 \mathrm{~s}$ merupakan sea state dengan jumlah kejadian tertinggi. Maka dominasi fatigue akan diperoleh dari sea state tersebut.

\section{F. Spektrum Gelombang}

Spektrum gelombang dibuat dengan mengacu pada persamaan (3) direpresentasikan dengan hubungan antara Hs dan frekuensi gelombang. Hasil dari salah satu spektrum dapat dilihat pada Gambar 1. Dapat dilihat bahwa nilai maksimum spectral density pada spektrum tersebut yaitu 0,75 $\mathrm{m}^{2}$.s pada Gambar 3 .

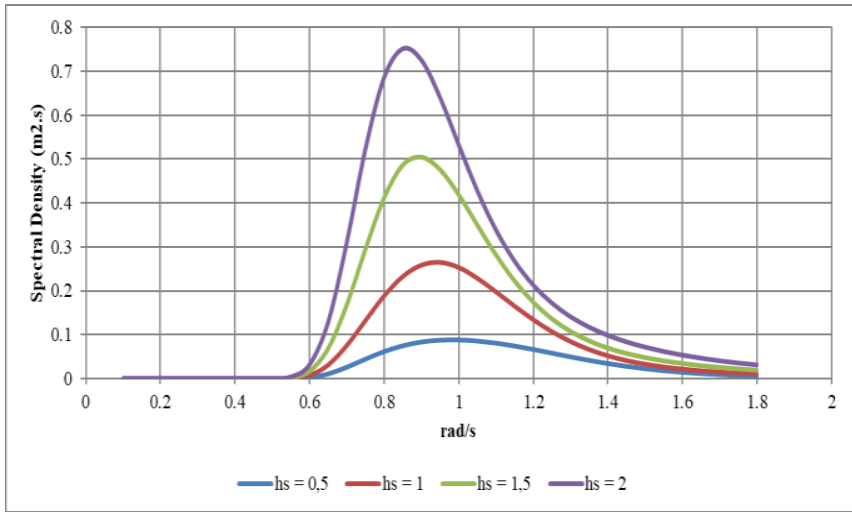

Gambar 1. Spektrum Gelombang Pada Zero-up Crossing $5 \mathrm{~s}$.

\section{G. RAO Kombinasi}

Sesuai dengan persamaan (4) hingga persamaan (7) maka dapat dilakukan. Besar RAO tegangan yang terjadi yaitu pada arah $135^{\circ}$ (berwarna merah) pada Gambar 4 atau quartering sea. Hal tersebut terjadi karena kombinasi antara tegangan vertikal dan horizontal yang dilakukan coupling sehingga resultan tegangan terjadi pada arah tersebut.

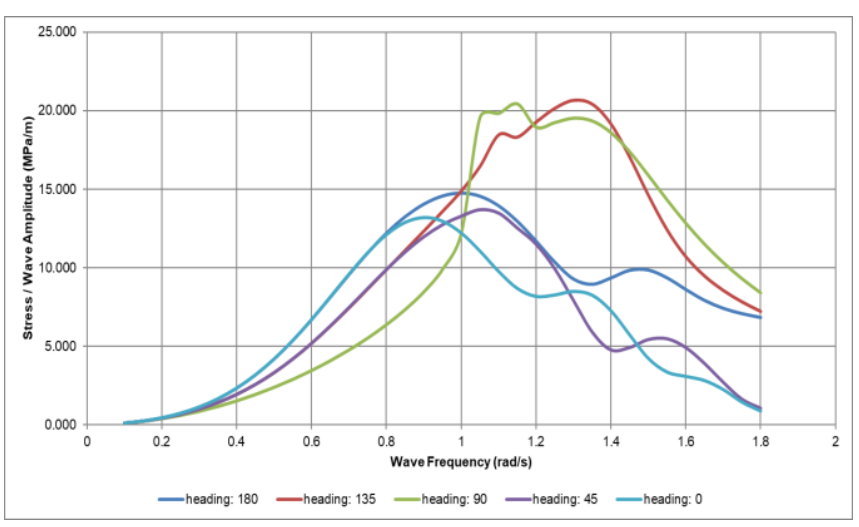

Gambar 2. RAO Kombinasi Tegangan Untuk Kasus Pembebanan Muatan Penuh.

\section{H. Spectral Moment}

Besaran moment yang dihasilkan pada response struktur akibat gelombang menunjukkan nilai maksimum berada pada $\mathrm{Hs}=2,5 \mathrm{~m}$. Hasil tersebut dapat dilihat pada Tabel 7 . Gambar tersebut sebagai contoh plot spectral moment.

Tabel 7.

Spectral Moment Orde ke-0 Kasus Pembebanan Muatan Penuh

\begin{tabular}{cccc}
\hline \hline \multirow{2}{*}{$\begin{array}{c}\mathrm{Hs} \\
(\mathrm{m})\end{array}$} & \multicolumn{3}{c}{ Heading $180^{\circ}$} \\
\cline { 2 - 4 } & 5 & 6 & 7 \\
\hline 1 & 7,1 & 10,3 & 12,3 \\
1.5 & 18,1 & 27,4 & 33,4 \\
2 & 30,9 & 50,0 & 63,0 \\
2.5 & 43,2 & 74,0 & 96,6 \\
\hline \hline
\end{tabular}

\section{Kelelahan \& Umur Struktur}

Dari hasil sebelumnya maka akan didapatkan besar kerusakan. Besar kerusakan tersebut merupakan faktor utama dalam kelelahan. Besar kerusakan tersebut dapat diperhatikan pada Tabel 8.

Tabel 8.

Persebaran Damage Untuk Muatan Penuh Arah Banyuwangi-Bali

\begin{tabular}{cccc}
\hline \hline Heading & \% Arah & $\mathrm{D}_{\text {hitung }}$ & $\mathrm{D}_{\text {terjadi }}$ \\
\hline 180 & $0.003 \%$ & 0.217762 & 0.0000 \\
135 & $44.244 \%$ & 0.314833 & 0.1393 \\
90 & $25.672 \%$ & 0.262412 & 0.0674 \\
45 & $28.820 \%$ & 0.138227 & 0.0398 \\
0 & $1.254 \%$ & 0.146526 & 0.0018 \\
-45 & $0.000 \%$ & 0.138227 & 0.0000 \\
-90 & $0.003 \%$ & 0.262412 & 0.0000 \\
-135 & $0.003 \%$ & 0.314833 & 0.0000 \\
\hline \hline
\end{tabular}

Kelelahan yang dialami struktur akibat gelombang didapatkan nilai maksimumnya pada heading $135^{\circ}$ (SE). Besar damage yang dihasilkan tanpa probabilitas heading yaitu 0,314833 untuk kasus pembebanan muatan penuh dan 0,21344 untuk kasus pembebanan muatan kosong. Untuk 
membuat skenario yang terjadi sebenarnya maka faktor probabilitas heading dimasukkan yang mengakibatkan besar damage menjadi 0,139294 untuk kasus pembebanan muatan penuh dan 0,094435 untuk kasus pembebanan muatan kosong. Sehingga total damage yang terjadi yaitu 0,496722 dan 0,319459 untuk muatan penuh dan muatan kosong secara berturut-turut. Umur struktur yang diakibatkan damage yaitu 20,13 tahun dan 31,30 tahun untuk muatan penuh dan muatan kosong. Sesuai dengan persamaan (13) maka kombinasi kasus pembebanan menyebabkan umur struktur selama 28,83 tahun.

\section{KESIMPULAN}

Setelah dilakukan percobaan maka kesimpulan dari penelitian ini yaitu:

1. Umur struktur untuk masing-masing kasus pembebanan didapatkan 20 tahun dan 31 tahun untuk muatan penuh dan muatan kosong secara berturut-turut dimana umur struktur pada masing-masing kasus pembebanan masih memenuhi kriteria yang disyaratkan ABS yaitu 20 tahun.

2. Umur struktur untuk kombinasi kasus pembebanan adalah 28 tahun dimana memenuhi kriteria yang disyaratkan ABS yaitu 20 tahun dengan faktor 0,85 yang direpresentasikan sebagai service life kapal dan terletak di antara umur struktur muatan penuh dan muatan kosong.

\section{UCAPAN TERIMA KASIH}

Ucapan terima kasih diperuntukkan untuk pihak Badan Meteorologi dan Geofisika (BMKG) Stasiun Maritim, Perak,
Surabaya atas kerja sama yang terjalin sehingga penelitian ini dapat terlaksana.

\section{DAFTAR PUSTAKA}

[1] R. Bhattacharya, Dynamic of Marine Vehicles. New York, 1978.

[2] American Bureau of Shipping (ABS), "Spectral-Based Fatigue Analysis for Vessels," Houston, 2016.

[3] E. K. Hasselmann, T.P. Barnett, H. Bouws, D. E. Carlson, K. Cartwright, J. A. Enke, H. Ewing, D. E. Gienapp, P. Hasselmann, A. Kruseman, P. Meerburg, D. J. Mller, K. Olbers, W. S. Richter, and H. Walde, "Measurements of wind-wave growth and swell decay during the Joint North Sea Wave Project (JONSWAP)," Ergnzungsh. zur Dtsch. Hydrogr. Zeitschrift R., vol. 8, no. 12, p. 95, 1973.

[4] M. Misbah, D. Setyawan, and W. M. Dananjaya, "Construction Strength Analysis of Landing Craft Tank Conversion To Passenger Ship Using Finite Element Method," J. Phys. Conf. Ser., 2018.

[5] S. H. Ardianus and D. S. Sujiatanti, "Analisa Kekuatan Konstruksi Sekat Melintang Kapal Tanker dengan Metode Elemen Hingga," J. Tek. ITS, vol. 6, no. 2, 2017.

[6] S. Chakrabarti, "Hydrodynamic of Offshore Structures," Boston, 1987.

[7] W. Weibull, Fatigue Testing and Analysis of Results. Oxford: Pergamon Press, 1961.

[8] D. Septiana, "Perkiraan Fatigue Life pada Bracket Kapal Tanker Berdasarkan Common Structural Rules," Institut Teknologi Sepuluh Nopember, 2012.

[9] M. Rusdi, M. Misbah, and T. Yulianto, "Analisis Fatigue Life pada Bracket Oil Tanker dengan Beban Sloshing," J. Tek. ITS, vol. 7, no. 1, 2018.

[10] M. Huda and B. Santosa, "Analisa Perkiraan Umur Struktur Pada Kapal Ikan Katamaran 10 GT Menggunakan Metode Elemen Hingga," J. Tek. ITS, 2012.

[11] A. Yustiawan and K. Suastika, "Prediksi Umur Kelelahan Struktur Keel Buoy Tsunami Dengan Metode Spectral Fatigue Analysis," $J$. Tek. ITS, vol. 1, no. 1, 2012. 